\title{
Breast Epithelioid Hemangioma
}

National Cancer Institute

\section{Source}

National Cancer Institute. Breast Epithelioid Hemangioma. NCI Thesaurus. Code C5211.

A hemangioma characterized by the presence of epithelioid endothelial cells, arising from the breast. 